in about two thirds of the subjects. Combined administration of mucopolysaccharides and anabolic steroids caused conspicuous reduction in lipid level and viscosity.

\section{Discussion and Conclusion}

It has been reported several times that loading with lipids produce increase in the viscosity of whole blood and of plasma, and it has been well established that intravenous injection of chylomicron, emulsified fat, or simillar large corpuscles increase blood viscosity and that administration of unsaturated fatty acids and low-fat diet reduces it. Epidemiological studies also have shown that blood viscosity is affected by dietary consumption of fat.

No report hitherto published, however, clarifies the relationship between the viscosity and the levels of specific lipid fractions. The present study of the author has revealed the existence of positive correlation between the viscosity and almost every lipid fraction. This common behavior of the fractions strongly indicate the probability that they exert their influence on the viscosity through some factor common to all of them, instead of independent$l y$, and that $\beta$-lipoprotein which is the main constituent of serum lipid fractions is mainly responsible for the influence.
The author and his coworkers also measured the viscosity of each individual fraction of the serum, and obtained high values for the $\beta$-globulin fraction. This may be regarded an evidence that $\beta$-lipoprotein plays some important role in raising the viscosity of blood.

Thus $\beta$-lipoprotein is considered to have much to do with the changes of serum viscosity due to anomalous lipid metabolism, the author measured the viscosity under the influence of lipoprotein lipase, and observed it became lower as the $\beta$-lipoprotein content decreased. Furthermore, it was found that when drugs which cause decrease of $\beta$-lipoprotein through correction of lipid metabolism are given to hyperlipemic subjects, the viscosity of their serum decreased. Therefore as far as the influence of lipids on serum viscosity is concerned, the role of $\beta$-lipoprotein must be called pretty important in augumenting the adhesion of blood cells and the viscosity of serum.

Many workers have reported that increase of $\beta$-lipoprotein plays some important part in the etiology of atherosclerosis. It is thought very probable that increase of $\beta$-lipoprotein causes atherosclerosis because it increases the viscosity of the fluid component of blood and the adhesiveness of its cellular components.

\title{
Studies on Atherosclerosis, Mainly about its Relationship with Serum Viscosity (II)
}

Toshio Shinagawa (2nd Department of Internal Medicine, School of Medicine, Kanazaza University, Kanazawa)

The etiology of athrosclerosis has been investigated from very many angles, not only from epidemiological considerations such as race, diet, and environment, but also from endocrinological, genetical, blood rheological, neurological, and comparative pathological considerations and in relation to sexes and constitution of body fluids. Very recently, a number of surface-active agents having the power of substantially modifying the physicochemical properties of blood lipids have been tentatively administered for the purpose of inhi- biting the occurrence of atherosclerosis. Also, as was reported in the First Report, the rheological properties of blood which are responsible for the transformation of the constituents of blood and the change of its flow characteristics have undergone gradual clarification.

It must be very pertinent to the study of the etiology and therapy of atherosclerosis to carry out clinical investigation of the physicochemical properties of blood and tissue cells. Regarding the relationship between the rheology of blood and atherosclerosis, increase of 
viscosity of whole blood is thought to be responsible for the development of atherosclerosis presumably through increase of some adhesive substances in the plasma having the property of making the cellular constituents stick together.

Therefore the author measured the viscosity of serum in animals with experimental atherosclerosis and in patients with diseases closely related to atherosclerosis, and studied the relationship between sclerosis and viscosity.

\section{Materials and Methods}

The method of measuring serum viscosity and the clinical subjects employed were the same as in the First Report. The experimental animals were 35 rabbits, of which 17 were fed on lanolin.

\section{Results}

1) The relationship between age and serum viscosity was as follows. The average viscosity in the 43 male patients under 40 years was 1.773 with standard deviation of 0.089 . The 36 females under 40 gave $1.773 \pm 0.081$, the 84 males of age 40 and over gave $1.847 \pm$ 0.108 , and the 46 females of the same age bracket gave $1.848 \pm 0.125$. Thus in each sex the higher age group had larger values of viscosity than the lower group, but there was found no significant difference between both sexes.

2) The average and the standard deviation were found to be 1.868 and 0.129 in the 15 patients with coronary diseases. The 73 hypertensive patients gave $1.830 \pm 0.094$, the 21 with cerebrovascular diseases gave $1.839 \pm$ 0.129 , and the 19 diabetics gave $1.833 \pm 0.113$, the values being decidedly higher than the value found in 15 healthy subjects in their twenties, which was $1.728 \pm 0.056$.

3) Some of the rabbits in which experimental atherosclerosis was produced by lanolin feeding showed serum viscosity markedly higher than the control animals. The average was $1.758 \pm 0.168$ for the 17 lanolin-fed rabbits and $1.553 \pm 0.080$ for the 18 controls.

\section{Discussion and Conclusion}

It has been reported that increase of blood viscosity occurs in patients with coronary diseases such as myocardial infarction and angina pectoris, and the high viscosity has been regarded to have important bearing on the etiology of these diseases. The high viscosity of whole blood may be regarded as a plausible and important cause of thrombus formation in arterioles of small bores such as those of the coronary arteries, but does not fully explain the fact that thrombi are formed and atherosclerosis occurs oftener in somewhat larger arteries. In relatively large arteries, the flow of blood near the intima is what really matters.

But in the part of the stream close to the intima, the blood mainly consists of the liquid components, and it is thought better for the objective in view to measure the viscosity of plasma or serum than that of whole blood.

The author therefore measured the viscosity of serum, and found the values to be higher in subjects above 40 of age than in those under 40 , who are less liable to atherosclerosis. The values were seen to be significantly higher in patients with coronary diseases, hypertension, cerebrovascular diseases and diabetes, which are regarded to be closely related to atherosclerosis, than in normal subjects. Furthermore, many of the rabbits with experimentally produced atherosclerosis were observed to have serum viscosity markedly higher than control animals. These findings indicate the probability that high serum viscosity is responsible for occurrence of atherosclerosis.

These results are also considered to be closely related to the anomalous lipid metabolism accompanying atherosclerosis.

Basing on the several results of observation described above, the author has shown the conclusion obtained from the equation of motion of viscous liquids. and the existence of positive correlation between the size of arteries and the frequency of occurrence of atherosclerosis in them as revealed by autopsy, and stressed the existence of close relationship between atherosclerosis and the rheological properties of blood. 


\title{
動脈硬化症に関する研究（第 2 報）
}

\author{
血清粘䅕度を中心として
}

\author{
品川俊男 \\ 金沢大学医学部第二内科（担当 村上元孝教授）
}

論文受理 昭和 38 年 9 月 17 日

\section{はじめに}

著者は前報において血清粘稠度と血清脂質との関係を 追求し，血清中 $\beta$-lipoprotein が粘稠度の増加に重要な 意義を有すること，そしてこの $\beta$-lipoprotein を介して の血清粘稠度の増加や細胞成分の粘着性增強などが，動 脈硬化の成り立ちに大きく関与している可能性のあるこ とを述べたが，本報においては，更に引続ぎ実験的動脈 硬化症および動脈硬化症に関係深いいくつかの臨床例に つい検討し，硬化の発現と血清粘稠度との関係につい て考察を加え若干知見を得たので報告する。

\section{実 験 方 法}

\section{A 血清粘稠度の測定}

Hess 氏粘稑度計（内径 $0.244 \mathrm{~mm}$ ) を用い, $17^{\circ} \mathrm{C}$, $-180 \mathrm{mmH}_{2} \mathrm{O}$ で蒸溜水と同時に测定し比粘稠度を算出 した。

B 测定対象

1. 臨床的考察

第 1 報におけると同一の症例について行なった。

\section{2. 家禹}

体重 2 3 kg の正常草食雄性家鬼 18 羽, 及び体重 2 $\sim 3 \mathrm{~kg}$ の雄性家㭸に $15 \%$ の割合にラノリンを添加した 固形飼料（オリエンタル醉母工業 R-C 5) を 1 日 $200 \mathrm{~g}$ ， 2 月投与したもの 17 羽について行なった。採血は 12 時 間以上の絶食後に行ない人の場合と同様に処理した。

\section{実 験 結 果}

\section{A 血清粘稠度と年令, 性}

血清粘稠度を测定した 211 例の比粘稠度を縦軸に，年 令を横軸にとりプロットしたのが Fig. 1 である。これ を各 10 年代ごとに区切り各々平均值を求めると Table I のごとくであり，今これを 40 才末満群と 40 才以上群 とに 2 大別して各々の平均值を求めると，40才未満群 78 例の平均值は $1.773 \pm 0.100 *, 40$ 才以上群 129 例の平 均値は $1.847 \pm 0.112$ となり，両群間には推計学的に明 らかに有意の差が認められる。

\footnotetext{
* Standard deviation
}

これを男女別に分けて平均值を求めると 40 才未満の 男子 43 例の平均值は $1.773 \pm 0.089,40$ 才以上の男子 84 例の平均値は $1.847 \pm 0.108,40$ 才未满の女子 36 例の平 均値は $1.773 \pm 0.081,40$ 才以上の女子 46 例の平均値は $1.848 \pm 0.125$ となり, 男女共に 40 才未満群と 40 才以上 群との間に有意の差が認められるが，男女間には 40 才 未満群においても，40才以上群においても有意の差は認 められなかった。

B 血清粘稠度と各種疾患

20〜30才の健康成人ならびに冠動脈疾患, 高血压症, 脳血管障害, 棓尿病等の動脈硬化症と関係深いと考えら れている疾患々者の血清粘稠度を測定し比較検討を行っ

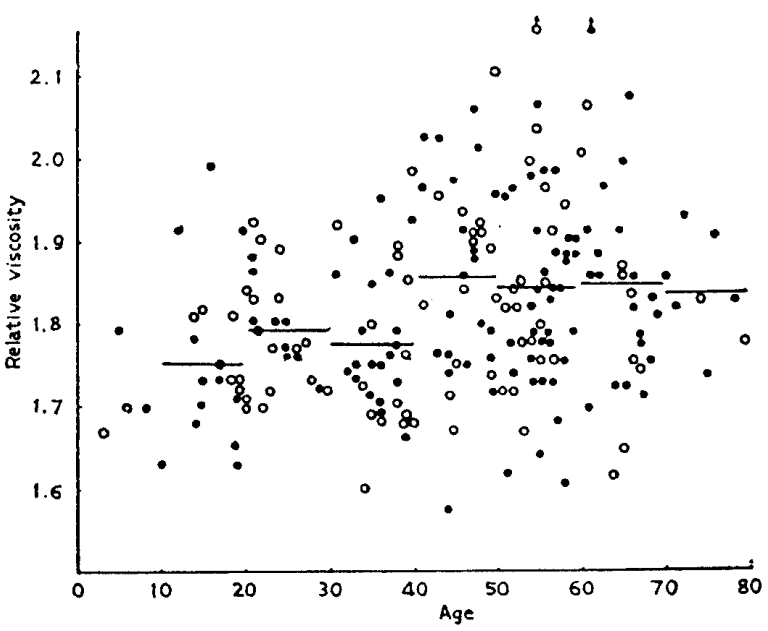

Fig. 1. Serum Viscosity in Various Age Groups male -, female o

TABLE I SERUM Viscosity IN VARIOUS AGE GROUPS

\begin{tabular}{c|c|c|c}
\hline Age & $\begin{array}{c}\text { Number of } \\
\text { Determina- } \\
\text { tion }\end{array}$ & Mean & $\begin{array}{c}\text { Standard } \\
\text { Deviation }\end{array}$ \\
\hline $10 \sim 19$ & 18 & 1.750 & 0.094 \\
$20 \sim 29$ & 27 & 1.791 & 0.099 \\
$30 \sim 39$ & 33 & 1.771 & 0.089 \\
$40 \sim 49$ & 33 & 1.856 & 0.116 \\
$50 \sim 59$ & 58 & 1.841 & 0.112 \\
$60 \sim 69$ & 30 & 1.848 & 0.121 \\
$70 \sim 80$ & 8 & 1.844 & 0.063 \\
\hline
\end{tabular}


た (Fig. 2).

健康成人 15 例の平均值は $1.728 \pm 0.056$, 冠動脈疾患 々者 15 例の平均值は $1.868 \pm 0.129$ で両者間には推計学 的に有意の差が認められる。高血圧症 73 例の平均值は $1.830 \pm 0.094$ であり，健康成人平均值との間に推計学的 に有意の差が認められる。高血圧症患者中，心電図撮影 を行ったものについてST 降下，T院性等の異常所見を 有する群と有しない群とに分けて平均值を求めると，有 所見群 31 例の平均値は $1.852 \pm 0.097$, 無所見群 24 例の 平均值は $1.792 \pm 0.088$ となり，両者間にはかなりの差 が認められるが，推計学的には必ずしも有意とはいいき れない $(0.05>\mathrm{p}>0.01)$. 又，無所見群においても健康 成人平均值に比し高値を示している $(0.05>p>0.01)$.

脳血管障害患者 21 例の平均值は $1.839 \pm 0.129$ ，陪尿 病者 19 例の平均値は $1.833 \pm 0.113$ で共に健康成人平均 值との間に有意の差が認められる。

すなわち, 動脈硬化性疾患々者は健康成人に比し，上 り高い卹清粘稠度を有する傾向があると云える。

C 契験的動脈硬化家㭸の血清粘稠度

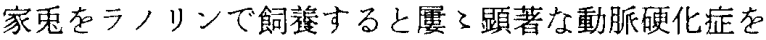
招来する。ラノリンを添加した飼料で飼養した家象は対 照の草食家秉に比し，著しく血清粘稠度の高いものが認 められ，対照平均 $1.553 \pm 0.080$ に対しラノリン飼養家

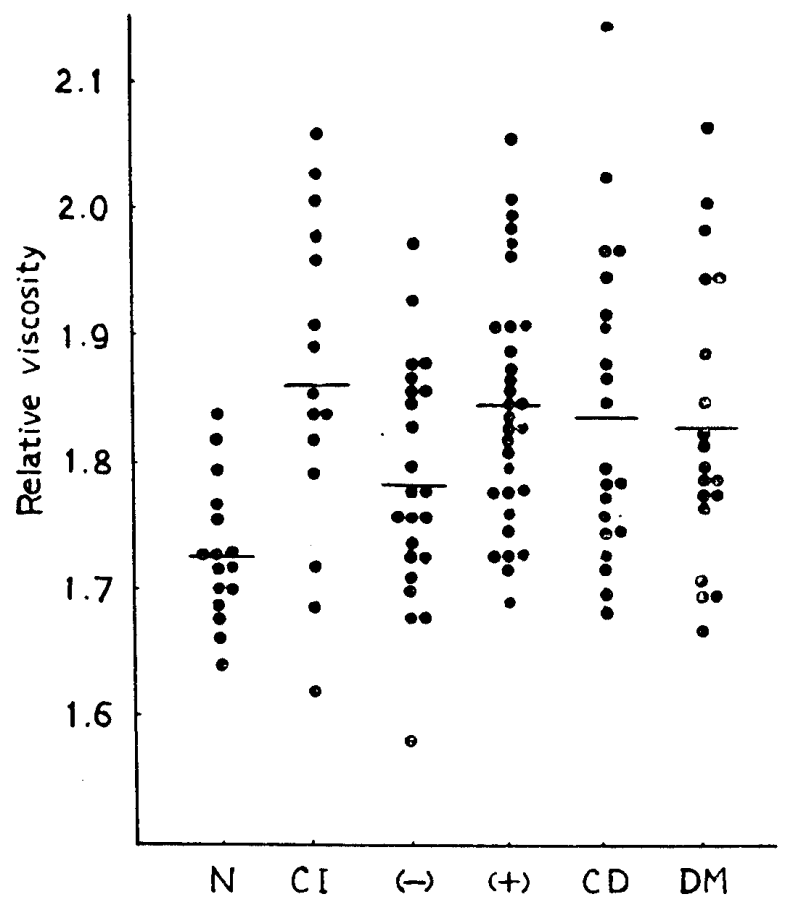

Fig. 2. Serum Viscosity in Various Diseases $\mathrm{N}$ : Normal

$\mathrm{CI}$ : Coronary Insufficiency

$(-)$ : Hypertension without Electrocardiographic Changes

(t); Hypertension with Electrocardiographic Changes

CD : Cerebrovascular Diseases

DM: Diabetes Mellitus
東平均 $1.754 \pm 0.168$ で両者の間に明らかに推計学的に 有意の差が認められた（Fig. 3).

$$
\text { 考按 }
$$

生体内での血液の流れや，その特性については従来か らかなり詳細に亘って物理化学的に種々検討がなされ， 多くの知見が得られているが，最近では Rheologyの立 場から新しく臨床と関連した面から再検討が加えられつ つある。従来，全血粘稠度と最も関倸深いものとして赤 血球容積があげられているが, 臨床例についてはBurch $5^{1) 2}$ )が心筫硬塞, 狭心症などの冠動脈疾患々者の多く が赤血球增多症を伴い，潟血による赤血球容積の減少と 粘稠度の减少により症状の改善されることを指摘してい る。また，心筋硬塞患者のへマトクリット值は正常人の それより高值を示す場合が多く，これに随伴して血液粘 稠度も増加し, 本症の成り立ちに血液粘稠度が重要な意 義をもつものと考えられている。

細管法で粘稜度を測定した場合，同じ血液でも血流が 遅い程粘稠度は大となることが知られており334. 生体 についても冠動脈疾患々者の病的な冠動脈では，狭窄部 の前部では血流速度の减少と側圧の増加から該部では一 層血液粘梏度は高まり，血流停止や血栓発生の危険が大 きいと云われている，血管壁の損稘を多く伴わない冠動 脈小枝の如き管腔半径の小さい血管で時点を等しくして 多発する血栓発生等の説明には, 血液粘稠度の增加は極 めて合理的且つ重要な要因として挙げることが出来よ

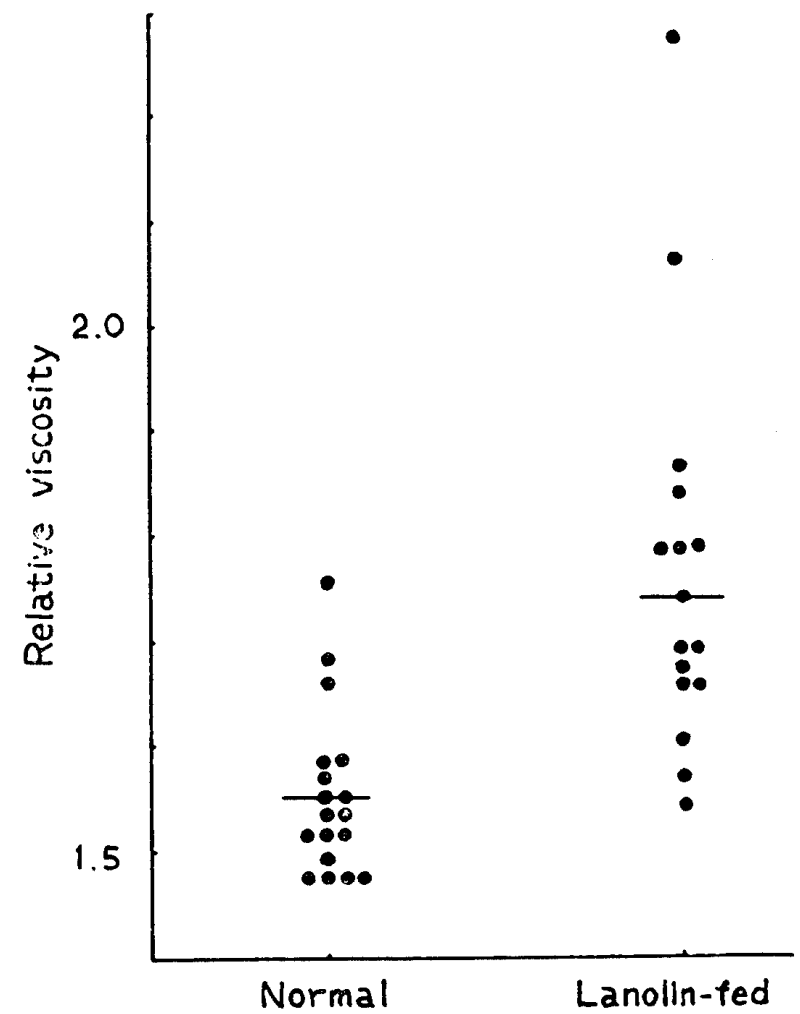

Fig. 3. Serum Viscosity in Normal and Lanolinfed Rabbits 
$う^{5)}$. しかしながら，一般に動脈硬化や血栓の発生し易 い大いさの動脈における動脈硬化あるいは血栓の形成に ついては，この上うな流体の特性の変化のみからは十分 な説明はなしがたい．この際，内膜表面に極く近接した 血液成分の流れが当然問題となるが，血管内における血 液構成要素の密度分布は必ずしも一様ではなく，axial streaming により赤血球は血管中心部を流れ，血管内膜 と血液の接触部分では, 細胞成分は僅かの血小板や遊走 細胞で，血液の液性成分がその主体をなすことが知られ ている67)．こういった実験成績から，硬化と粘稠度と のより密接な関係を追求するためには血液の成分中，液 性成分の特性との関連を明らかにする方がより合目的で あろう。よって，著者は前報でものべたごとく動脈硬化 症とのつながりを明らかにする目的から，粘稠度と脂質 との関倸をより正しく観察するためには粘稠度に影響を 及代す他の因子の関与が少く，正確な測定值の得られる ことが望ましいという点を考慮して，従来の諸家とは異 った見解から，血清を対象として測定し，粘稠度と臨床 面との関係について考察を加えた。

前報にも述べたごとく，血清粘稠度が若し脂質代謝異 常を介して動脈硬化症の成り立ちに関与するならば，脂 質代謝の歪のくる年令や疾患で血清粘稠度に異常の来る ことが予想される、著者の湘定例を年代別にみると動脈 硬化症の多発してくる40才台以後において動脈硬化症 の少ない 40 才以下に比し, 明らかに血清粘䅕度の増加 が認められ，Swank ${ }^{8}$ が viscosity index と年令との間 に認めた関係や，Hess ${ }^{9}$ が自作の粘度計によった初期の 成績ともかなりよく似た傾向をしめしている。この所見 は血清脂質代謝異常が同様に各年代に变化がみられると

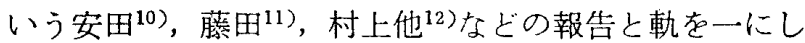
ており，両者の関係を推定する上に極めて興味深い。従 来, 血清粘稠度はアルブミンとはあまり関係なくグロブ リン分画と深いつながりをもつとされ13) 15), 年令と共 に相対的なアルブミンの堿少，グロブリンの增加を伴う 総蛋白絶対量の減少が認められているが16) 18)，グロブ リンの絶対值のみから粘稠度の变化を説明することは出 来ず，グロブリン分画中の質的に特別な分画の関与が考 えら机る。 $\beta$-lipoprotein をも含んだ $\beta$-globulin の增加 が albumin 减少とともに目立った变化を示すことが本 邦人についても明らかにされているが(17)18), 前報の成績 と考え併せて本分画の意義は極めて大きいということが 出来よう。

脳血管障害例や糖尿病例で高い血摮粘稠度が観察され ている ${ }^{19)}$. 動脈硬化と血清粘稠度との関倸については,

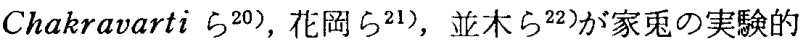
動脈硬化症について論じたものや，田中ら吕が小数例の 動脈硬化患者について測定した報告があるが，臨床面か ら系統的な考察を加えたものは見られない上うである。 著者の成績では冠疾患, 高血圧症, 脳血管障害, 稦尿病 などの動脈硬化症と関係深いと思われる疾患ではいずれ
も正常者に比し，血清粘䅕度は有意の增加を示しており， このいずれの疾患についても前述の成績と同样, 矢張り 脂質代謝異常のあることが明らかにされている10) 12)24).

脂質代謝と血液粘稠度との関係については先の報告で ものべたが，いずれも血液粘稠度の増加を来すことが明 らかにされており，これに伴う血球成分の粘着性の增加 やこれによる喰食促進から硬化進展が起るともいわれ25)， この変化が低脂肪食により改善されること及び lipoprotein lipase 在作用させることにより, 粘稠度の減少がみ とめられることなどから村上ら ${ }^{24)}$ の指摘した清浄因子系 列の障害ともからんで，硬化発現に演ずる粘稠度の增加 はかなり重要な意義をもつものと思われる。

又，実験的動脈硬化家雨については Chakravarti 等51) は, 血清粘秱度の增加と硬化の発現が平行関係にあると いい，血清脂質の增加も粘秱度の增加に関係があるとし ているが，著者もほぼこれ上同様の結果を得た．特にSf 10-30の lipoprotein の增加が粘䅕度の增加に重要な 関倸をもつと考えら记 ${ }^{26)}$ ，この globulin 分画は脂質の transporter としてのみでなく，その物理化学的特性の 1つからも硬化の発現や進展に大きな役割を演じている といえよう。

次に血液粘稠度と関連走もった流体力学的な面から， 動脈硬化の発現について若干考察を加えてみることにす る.

先に著者は動脈の内膜近接部を問題として，一部とり上 げたが，該部では血流は中心部に比して非常に緩徐であ るとされている( ${ }^{6)}$. 動脈の内膜表面近接部のところでの 血流速度を水平管内を均一な液体が層流をなして流れて いると仮定して検討在加えてみた。

$u, v, w$ をそれぞれ $x, y, z$ 軸方向の速度, $p$ を圧力, $\rho$ を密度, $\mu$ を粘性係数とすると, 非王縮性粘性流体の 運動方程式依

$$
\begin{aligned}
\frac{\partial u}{\partial t}+ & u \frac{\partial u}{\partial x}+v \frac{\partial u}{\partial y}+w \frac{\partial u}{\partial z} \\
& =X-\frac{1}{\rho} \cdot \frac{\partial p}{\partial x}+\frac{\mu}{n}\left(\frac{\partial^{2} u}{\partial x^{2}}+\frac{\partial^{2} u}{\partial y^{2}}+\frac{\partial^{2} u}{\partial z^{2}}\right) \\
\frac{\partial v}{\partial t}+ & u \frac{\partial v}{\partial x}+v \frac{\partial v}{\partial y}+w \frac{\partial v}{\partial z} \\
& =Y-\frac{1}{\rho} \cdot \frac{\partial p}{\partial y}+\frac{\mu}{\rho}\left(\frac{\partial^{2} v}{\partial x^{2}}+\frac{\partial^{2} v}{\partial y^{2}}+-\frac{\partial^{2} v}{\partial z^{2}}\right) \\
\frac{\partial w}{\partial t} & +u \frac{\partial w}{\partial x}+v \frac{\partial w}{\partial y}+w \frac{\partial w}{\partial z} \\
& =Z-\frac{1}{\rho} \cdot \frac{\partial p}{\partial z}+\frac{\mu}{\rho}\left(\frac{\partial^{2} w}{\partial x^{2}}+\frac{\partial^{2} w}{\partial y^{2}}+\frac{\partial^{2} w}{\partial z^{2}}\right)
\end{aligned}
$$

で与えられ，この場合の連続方程式は

$$
\frac{\partial u}{\partial x}+\frac{\partial v}{\partial y}+\frac{\partial w}{\partial z}=0
$$

である。今水平管内軸心を $X$ 軸にとる。運動方程式の $X$ 軸方向のものは,

$$
\frac{\partial u}{\partial t}+u \frac{\partial u}{\partial x}+v \frac{\partial u}{\partial y}+w \frac{\partial u}{\partial z}
$$

Japanese Circulation Jourual Vol. 28, May $19^{64}$ 


$$
=X-\frac{1}{\rho} \cdot \frac{\partial p}{\partial x}+\frac{\mu}{\rho}\left(\frac{\partial^{2} u}{\partial x^{2}}+\frac{\partial^{2} u}{\partial y^{2}}+\frac{\partial^{2} u}{\partial z^{2}}\right)
$$

となる．真直な円管で層流では $v=0, w=0, \partial u / \partial x=0$, 定常流と仮定すれば $\partial u / \partial t=0$

又, 今の場合 $\mathrm{X}=0$ だから

$$
-\frac{1}{\rho} \cdot \frac{\partial p}{\partial x}+\frac{\mu}{\rho}\left(\frac{\partial^{2} u}{\partial y^{2}}+\frac{\partial^{2} u}{\partial z^{2}}\right)=0
$$

$y=r \cos \theta, z=r \sin \theta$ にとり(2)变形すると

$$
-\frac{1}{\rho} \cdot \frac{\partial p}{\partial x}+\frac{\mu}{\rho}\left(\frac{d^{2} u}{d r^{2}}+\frac{1}{r} \cdot \frac{d u}{d r}\right)=0
$$

両辺に $\rho r$ を加移項すると

$$
\frac{d}{d r}\left(r \frac{d u}{d r}\right)=\frac{r}{\mu} \cdot \frac{\partial p}{\partial x}
$$

一様な真直な管内の流れでは压力勾配 $\partial p / \partial x$ は一定で あるから長さ $l$ 管の両端の圧力をそれぞれ $p_{1}, p_{2}$ と すれば

$$
\begin{gathered}
\frac{\partial p}{\partial x}=\frac{p_{2}-p_{1}}{l} \text { であり，これを(4)に代入すれば } \\
\frac{d}{d r}\left(r \frac{d u}{d r}\right)=\frac{p_{2}-p_{1}}{\mu l} r
\end{gathered}
$$

(5)をrについて積分すると

$$
u=\frac{p_{2}-p_{1}}{4 \mu l} r^{2}+c_{1} \log r+c_{2}
$$

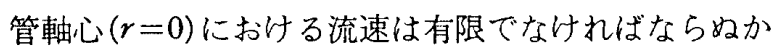
$c_{1}=0$, 又管壁 $(r=a)$ において $u=0$ でなければならぬ から

$$
\begin{gathered}
c_{2}=-\left(p_{2}-p_{1}\right) a^{2} / 4 \mu l \text { 従っ } \\
u=\frac{p_{2}-p_{1}}{4 \mu l}\left(a^{2}-r^{2}\right)
\end{gathered}
$$

管軸心 $(r=0)$ において流速 $u$ は最大になりこれを u

$$
u_{\mathrm{m} 1 \mathrm{ax}}=\frac{p_{1}-p_{2}}{4 \mu l} a^{2}
$$

(7)及び(8)より

$$
u=u_{\max }\left(1-\frac{r^{2}}{a^{2}}\right)
$$

血管壁表面に非常に近い距離 $\Delta h$ の部における流れの 速さを视とすると

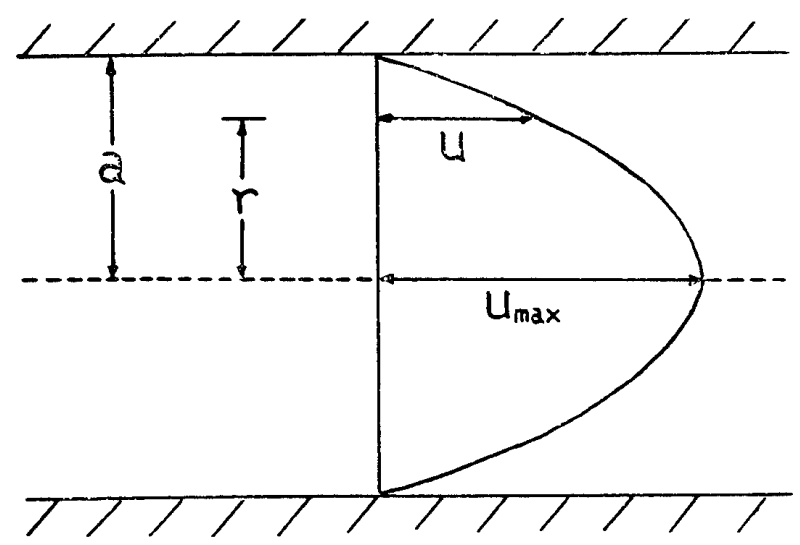

Fig. 4.

$$
u_{\Delta h} \doteqdot \frac{2 \Delta h \cdot u_{\mathrm{max}}}{a}
$$

動脈の平均血流速度 $u_{m}=\frac{1}{\pi a^{2}} \int_{0}^{a} u 2 \pi r d r=\frac{1}{2} u_{\mathrm{max}}$ は かなり小さい動脈に到る迄あまり减少しないから 動脈の内径に反比例することになる，少くとも，䂾状硬 化症が問題となる程度の大ささの血管ではこの関係がな り立つものと考えられる。

上記の数式は，Newton 流体についてのものであるが， non-Newtonian の場合にも定性的には正しい，nonNewtonian では流速が遅いと速い場合に比較して粘稠 度は大となるから粘稠度の影響は一層大となるものと思 わ扎る。

勿論，血管は一様な管ではなく，弾力性を有しており 又血流は定常流でなく，血液の円管内における分布も 一椂ではない。中心部と周辺部では密度を異にし，又 unsheared lamina 老考えねばならないかも知れないが， いずれにしても一般的には内径の大なる動脈は小なる動 脈に比し，内膜表面近接部では粘稠度の影響を被り易い ということが出来よう。

動脈硬化は全身に一様に来るものではなく，動脈の部 位により，動脈硬化発現の頻度もかなり異っていること が知られている27)28). 腹部大動脈, 総腸骨動脈, 外腸骨 動脈, 鎖骨下動脈, 総頸動脈, 上腕動脈, 橈骨動脈とい った血行力学的に圧・速度等がかなり近似しているよう な動脈を，田所 $\left.{ }^{29}\right) の$ 計測值に従い内径の順に比較検討す ると, 関28)が 514 例の剖検例について報告した動脈硬化 発現頻度の順位とかなりよく一致する。このことは上述 の考察と照らし合わせ極めて興味深く, 硬化の発現と血 液の rheological propertyがかなり梁いつながりをも っているものと言うことが出来よう.

\section{結語}

動脈硬化症発現と血清粘稠度との関係について，臨床 的および家鬼を用いた実験的動脈硬化症に検討を加え次 の結果を得た。

1. 血清粘稠度は，人においては 40 才以上のものは 40 才以下のものに比し高値を示した。

2. 冠疾患, 高血圧症, 脳血管障害, 楉尿病のごとき 動脈硬化と関係の深い疾患では対照に比し，血清粘稠度 は高值を示した。

3. 実験的動脈硬化発現家鬼では対照家秉に比し, 血 清粘稠度は著しく高い値を示した。

4. 血清粘稠度の動脈硬化症に及ほすす意義を脂質代謝 と臨床面とのつながりについて， Rheology に関連した 分野から若干考察を加えた。

終りに御指導, 御校閲を睗った恩師村上教授並び御助言を䁑った 横兵国立大学武藤教授に患心より感謝いたしますと共に日夜御指導， 御䂓揵を戴いた閔本博士に愿く感懒いたします。

本諭文の要旨は昭和 37 年 3 月, 第 26 回日本循環器学会総会, 昭和

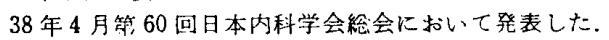




\section{REFERENCES}

1) Burch, G.E., De Pasquale, N.P., Am. Heart J. 62 : 139, 1961

2) Burch, G.E., De Pasquale, N.P., Am. J. Med. 32 : 116, 1962

3) Wells, R.E. Jr., Merrill, E.W., J. Clin. Invest. $41:$ 1591, 1962

4) Wells, R.E. Jr., Merrill, E.W., Science 133 : 763, 1961

5) Block, E.H., Am. J. Med. Sci. 229: 280, 1955

6) Fåhraeus, R., Physiol. Rev. 9: 241, 1929

7) Eckstein, R.W., Book, D., Gregg, D.E., Am. J. Physiol. 135 : 772, 1942.

8) Swank, R.L., Am. J. Clin. Nutr. 19 : 418, 1962

9) Hess, W., Deutsch. Arch. Klin. Med. 94: 404, 1908

10）安田義顕，日循誌，27:519, 1963

11) 藤田嘉文，日循誌，25:732，1962

12）村上元孝，他，綜合臨牀，9:107，1960

13) Rohrer, F., Deutsch. Arch. Klin. Med. 121 : 221,1917
14）茂在照, 東京医学会雑誌, $37: 662,1923$

15）吉川春寿, 医学のあゆみ, $3: 171,1947$

16) Köppel, J., Z. Altersforschg 2 : 220, 1940

17) 熊谷辡，東京慈恵医大誌，66:154，1952

18）近新五郎，生物物理化学，2:199, 1955

19) Swank, R.L., Neurology 9 : 553, 1959

20) Chakravarti, R.N., Balkrishna, Zaidi, S.H. J. Jeront. $17: 27,1962$

21）花岡正已，他，日本病理学会会誌，27:301，1937

22）並木正已，他，内分泌及実験治療，6(6)：843，1938

23）田中博太郎，他，日本血液学会雑誌，1(1)：111, 1937

24）村上元孝, 他, 治療, 44:1，1962

25) Florey, H., Brit. Med. J. 2 : 1329, 1960

26) Goffman, J.W., Lindqvist, F., Elliote, H., Mantz, W., Hewitt, T., Stvinser, B., Herring, V., Science $111: 166,1950$

27) Schwarz, C.J., Mitchel, J.R.A., Circ. Res. $11: 63$, 1962

28）関增爾，老年病，4:21，1960

29) 田所豊, 解剖学䧱誌, 2(5) : 718, 1929 